\title{
Effect of Leadership Behaviour on Teacher's Performance and Self-Learning
}

\author{
Debora \\ Faculty of Teaching and Learning \\ Universitas Palangka Raya \\ J1. H.Timang Kampus Universitas Palangka Raya 73112, Indonesia \\ debora@fkip.upr.ac.id
}

\begin{abstract}
Leadership behavior is a crucial in an organization, self-learning, and performance teacher as well as on the school. While the teacher's performance also depends it's on how teachers develop his/her potential which also affects the performance of his accomplishments. The research looked directly influence the behavior of school leadership on teacher performance and also how teachers developed their potential through self-learning. The process of research is quantitative research with survey method by which a causal approach flow system in one direction, so there is no reverse direction by using the technique of path analysis. The study was conducted on $\mathbf{7 4}$ people vocational teachers in Palangka Raya city of Central Kalimantan in Indonesia. The average scores for 38 teacher performance items ranged from 2.08 to 4.42 out of a total 5 . The average scores for 40 leadership behavior items ranged from 2.08 to 4.34 out of a total of 5 , and the average scores for 25 selflearning teacher items ranged from 2.76 to 5.00 out of a total score 5. The result showed that there was affect positive direct among leadership behavior and Self-learning on performance, but does not directly influence for leadership behavior to selflearning teachers. This research is interesting and in support of lifelong learning for teachers and how the teachers established itself as a facilitator and motivator in learning.
\end{abstract}

Keywords: leadership behavior; life-long learning; performance; self- learning.

\section{INTRODUCTION}

An effective leader is a leader which use the style of leadership that can realize the target, for example by delegating tasks, conduct the effective communication, motivate subordinates, implement controls and so on. So it, the effectiveness of leadership related to behavior and leadership style which is owned by a leader. This behavior will be visible from the attitude and actions of a leader in did anything. Development and the innovation on leadership have been carried Principal as educational leaders in the school has an emphasis on the importance of leadership positions to improve the quality and the effectiveness of the school [1], [2] [3], [4], [5], [6]. Leadership is important in the management of a school [7] with leadership behavior, but how about on teacher self-learning? The research of Leadership distinguishes between leadership as a leader, role or position which is then focused on the improvement of learning in three areas, namely the investment of staffing and other resources in support of equitable learning improvement, the development and exercise of distributed instructional leadership within the school, and the transformation of central office work practices and the district-school relationship to develop and sustain instructional leadership capacity [8]. This shows that schoo leadership is an important component besides the teacher that determines as a cutting edge in learning. Motivation to learn that was developed by the teacher in learning as does the distance learning models [9] as well as the teacher trained in the use of project-based learning [10], everything was done for the improvement of learning in the classroom of the estuary is for improving education. The teacher can do also learning innovation for effective through self-regulated learning [11]. With the Self-Regulated learning, students will be more motivated [8] which is also in synergy with the cooperative learning which will enhance the cognitive level, metacognitive and also the motivational skills in students as a picture of student success on his/her study [7], [12]. The results showed that self-regulated learning, cooperative learning, and Academic Self-Efficacy will prevent the school failure [13]. It is inseparable from of performance of a teacher in his role as a mentor, coach, motivator, and facilitator. Teacher 's performance can not be separated from the learning performed on him as someone who spearheading the of learning must be taught how to learn. so that of the learning it will last a lifetime. Therefore, this study investigates how self-learning effect on performance Teacher that support the occurrence self-regulation, cooperative learning and the academic SelfEfficacy which also not free anyway in the role of as the principal's leadership in the behavior its leadership. Performance is a combination of the motivation factors by efforts, abilities, and accuracy of perception the role of and is seen as the work that was formed because of his ability of the capacity to perform, opportunity to perform, and willingness to perform [14], [15]. Can the teacher featuring it's performance the task and his role as a teacher which starts from doing the planning the learning, the implementation of learning up to the evaluation. cording to the theory of "SelfEfficacy" from Gist and Mitchel, in which there understand the concept of performance. "Self-Efficacy" is the highest component of the personality, which is the belief that one of the potentials in performing the task. Whether the concept of "Self-Efficacy" in which there are two main things which become the basis of the person to look back (feedback) will be its performance in the past can be done well? How do that way which will then appear in its performance ?. Due to directly factors experience gained from its experiences own in the past to do a job, and the second factor, the experience of the others which used for his own experience to do a job can only be done if the teacher never stops for learning. Whereas the 
performance of a result of the learning [16]. The construction of motivation, self-efficacy, self-regulated learning until that impact on the success in the performance of the students as a success factor [7], [13], [16], but how can to these factors to do success? Because education is a system involving many components that one important component is the Fig. of a teacher in the classroom. Similarly, the principal as leader of education in schools is an important component as a which manager of its leadership behaviors for affecting the quality of education in schools. So the teacher as a coach, mentor, motivator in the classroom is required to have self-learning as Fig. teacher good for the continuation of lifelong learning. Therefore it this research straining to see the direct influence of the behavior of school leadership on performance and selflearning teacher, for motivation, self-efficacy, to the selfregulated learning that impact on the success in the performance of their students as success factors will not to work properly if not supported by the behavior of school leadership and self-learning that is owned by the teacher.

So, if theoretically the behavior of school leadership there are two (2) orientation, ie, first, the behavior of a task-oriented leadership and second, the relationship-oriented behavior. The behavior of school leadership which task-oriented are: a. The Leaders directing the teacher for the performed task; b. Determine the procedure or method in the effective task completion; c. Outlining the work in detail; $d$. The standard on the job; e. Specify a time limit in work; f. Affect the commitment and adherence to the task of achieving the goal; g. Coaching the teachers for doing its job. Whereas, behaviors leadership activities orientated to the relationship are following: a. The Support to the organization members (teachers) in the authority of duty; b. Be fair; c. Into account the views the teacher; d. Put himself level with the subordinate; e. Friendship; f. Exemplary; g. Cooperation; h. Provide motivation and drive to achieve organizational goals; i. Digging and empower all teachers; j.The Creating of communication links. But, this research is the difference of theory leadership behavior toward employees. [17], [18]. This research very important toward the performance for a teacher at the school in the learning process.

Leadership in education is very complex if you want to become effective principals and good quality [19], [20], then by this research will look at how the direct influence of behaviors leadership on performance and teachers' selflearning and self-learning the direct influence teachers on their performance. Performance in the implementation of the tasks and role as a teacher who starting from the first, do the lesson to plans prepared by teachers. The teacher makes the formulation learning objectives; develop and organize materials, instructional media, and learning resources; scenario planning learning activities, designing classroom management; planning procedures, and prepare an assessment too.

Second, the implementation of learning who teachers do with instructional the space and facilities management; implement the learning activities; manage the classroom interactions; being open and flexibility, as well as help students, develop positive attitudes toward learning; which demonstrate specialized ability in the learning do certain subjects; and third in the evaluation of the learning results, judging from how teachers can implement the evaluation process, and implementing the learning outcomes. Whereas, self-learning is a person's ability in this regard teachers in developing the capacity of himself as who learn on characterized with the mindset change was obtained from the ability of teachers to perform self-assessment, selfimprovement agendas, and strengthening of self. Learning is an important thing to do an activity that will appear as a performance someone [16]. Self-learning was high or low teacher's as a form of lifelong learning who teacher do is a manifestation of self-efficacy and motivation to learn.

Another research to review explores the effects of selfassessment on students' self-regulated learning (SRL) and selfefficacy [21] and appearance of the influence of other components which allegedly provided the direct influence teacher which determine high or low self-regulated learning and cooperative learning in the classroom who the teacher apply [13]. But this research, it shows that self-learning how about the teacher in performance he/she do self-assessment, self-improvement agendas. One study of the adult learner as part of a continuous learning [22] states that it is important for teachers to Ensure the needs to be addressed accurately through various teaching and learning activity. So to answer that teachers must have a self-learning is high and this is one answer from the results of research conducted by Salleh [22] about the need for teachers to be dealt with accurately through various teaching and learning activity. These results point to the importance of self-learning in teacher performance because the leadership behavior is not directly influencing on teacher self-learning.

\section{METHODS}

This research used survey with quantitative approach. In this research was used a technique of path analysis to get the effect of leadership behavior on performance teacher, and selflearning teacher's performance, just to leadership behavior. Data collection was used questionnaire instrument model Likert's 1-5. The population of vocational teacher is 276 and with proportional random sampling get the sample of 74 (from Slovin formula and used combination Nomogram Harry King Formula) [23]

Assessment Instrument performance using a rating scale (rating scale) with alternative answers, that is: as always, often, fairly often, rarely and had never. The alternative answers are given weight value five to one for a positive statement and the weight value of one to five to negative statements. Performance instrument a questionnaire consisting of forty-four grains of the item. Thereby hence the theoretical range of scores between forty-four and the 220. The validity of performance conducted with the aid of Microsoft Excel computer software. The validity of each item the declared valid if value $r_{\text {hitung }}>$ table. Nilai table for $n=20, \alpha=0.05$ is equal to 0,444 . From forty-four grains of items, which deciduous 6 grains of items, so it was used for research, were 38 items Cronbach's $\alpha=0.914$.

The validity of the instrument of leadership behavior, of 40 items based on a calculation of all valid, the reliability of the 
instrument, Cronbach $\alpha=0.953$. Instrument self-learning of 26 items, only 1 (one) point items that are not valid and should be dropped, so that the reliability of the Self-Learning as much as 25 of the questions, then obtained a Cronbach $\alpha=0.79$.

\section{A. Statistical Analyses.}

The inferential analysis is used to test the research hypothesis by using path analysis which is preceded by test requirements analysis in the form of calculation and testing of normality and linearity testing. First, the requirements analysis test including normality test and significance tests performed prior to testing hypotheses with the regression linearity. An error distribution normality test by using tests Lilies. Terms fault is if the statistical test, $\mathrm{L}_{0}<\mathrm{L}_{\text {table }}(\alpha=0.05)$, then the data are normally distributed. But when $\mathrm{L}_{0}>\mathrm{L}_{\text {table }}$, the data were not normally distributed. The Significance Tests of Coefficient Linearity of Regression and correlation. Second, Analysis correlation to testing of linearity and significant with the regression equation and the final analysis is done by calculating linear equation using a correlation coefficient to find the value of the coefficient of a determinant, which shows the influence of variables. Structural model of the in this research presented again like seen in Fig. 1. In the research pathways analysis models that are used is recursive models (model one way) then the path coefficient using simple correlation coefficient.

\section{RESULT \& DISCUSSION}

The average scores for 38 teachers performance item ranged from 2.08 to 4.42 out of a total 5. The average scores for 40 leadership behavior items ranged from 2.08 to 4.34 out of a total of 5 , and the average scores for 25 self-learning teacher items ranged from 2.76 to 5.00 out of a total score 5 . Data Normality Test Scores are above Error Performance of Leadership Behaviors. The results of calculation obtained by value $L_{0}$, the highest, $L_{\text {arithmetic }}=0.0698$. A smaller value than value $\mathrm{L}_{\text {table }}(\mathrm{n}=74$ and $\alpha=0.05)=0.103$ and $\mathrm{L}_{\text {table }}(\alpha=0.01)$ $=0.1178$. (Thus it can be said that the performance $(\mathrm{Y})$ and the Behavioral Leadership $\left(X_{1}\right)$ are derived from a normally distributed population. Data normality test scores are above error performance of Self-Learning. The results of calculation obtained by value $\mathrm{L}_{0}$, the highest, $\mathrm{L}_{\text {arithmetic }}=0,076$. A smaller value than value $T_{\text {able }}(n=74$ and $\alpha=0.05)=0.103$ and $T_{\text {able }}$ $(\alpha=0.01)=0.1178$. (Thus it can be said that the performance (Y) and the Self-Learning $\left(\mathrm{X}_{2}\right)$ is derived from a normally distributed population. Data Normality Test Scores above Error Self-Learning $\left(\mathrm{X}_{2}\right)$ of Leadership Behaviors $\left(\mathrm{X}_{1}\right)$.

Table I shows From the calculation of $12.1298 \mathrm{~F}$ value regression model. While in the real level of $\alpha=0.05$ was obtained $\mathrm{F}_{\text {table }}=3.96$; and the the real level $\alpha=0.01$ was obtained $\mathrm{F}_{\text {table }}=6.97$, then the regression coefficient is significant and the regression equation $\bar{Y}=99.718+0,385 X_{1}$. Furthermore, the linearity test, the results of calculations obtained $F_{\text {value }}-0.2488$. While in the real level of $\alpha=0.05$ was obtained $F_{\text {table }}=3.96$, and the the real level $\alpha=0.01$, obtained $\mathrm{F}_{\text {table }}=8.02$. Because of $\mathrm{F}=-0.2488<\mathrm{F}$ table, then shaped linear the regression. Table 2 shows Significance and Linearity Performance (Y) on Self-Learning $\left(\mathrm{X}_{2}\right)$, Significance test calculation and linearity performance (Y) on SelfLearning $\left(\mathrm{X}_{2}\right)$ produced the regression $\overline{\mathrm{Y}}=96,907+0,519 \mathrm{X}_{2}$.
Next table 3, show Significance test calculation and linearity Self-Learning $\left(\mathrm{X}_{2}\right)$ on Leadership Behaviors $(\mathrm{X} 1)$ produced the regression equation $X_{2}=X_{3}=92,902+0,0756 X_{1}$.

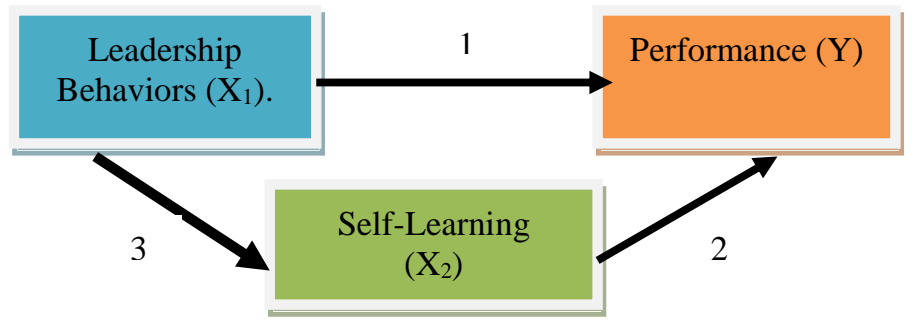

Fig 1. The Hypothetical Models Research

TABLE I. SIGNIFICANCE TESTS AND THE ANOVA FOR LINEARITY $\bar{Y}$ $=99.718+0,385 \mathrm{X}_{1}$.

\begin{tabular}{|r|r|r|r|r|r|r|}
\hline Source & df & $\begin{array}{c}\text { Sum of } \\
\text { Squares }\end{array}$ & $\begin{array}{c}\text { Mean } \\
\text { Squares }\end{array}$ & F value & \multicolumn{2}{|c|}{ F $_{\text {table }}$} \\
\cline { 5 - 7 } & & & & $\begin{array}{r}\alpha= \\
0,05\end{array}$ & $\begin{array}{r}\alpha= \\
0,01\end{array}$ \\
\hline Total & 74 & 1713505 & & & & \\
\hline Reg (a) & 1 & 1673711 & 1673711 & & & \\
\hline $\begin{array}{r}\text { Reg } \\
\text { (b/a) }\end{array}$ & 1 & 4949,71 & 4949,71 & 12,1298 & 3,96 & 6,97 \\
\hline Residual & 72 & 34844 & 483,94 & & & \\
\hline Tuna fit & 51 & 74324,1 & 1548,42 & $-0,2488$ & 4,32 & 8,02 \\
\hline an error & 24 & -39480 & -1645 & & & \\
\hline
\end{tabular}

TABLE II. SIGNIFICANCE TESTS AND THE ANOVA FOR LINEARITY $\bar{Y}=96,907+0,519 X_{2}$

\begin{tabular}{|r|c|c|c|c|c|c|}
\hline Source & df & $\begin{array}{c}\text { Sum of } \\
\text { Squares }\end{array}$ & $\begin{array}{c}\text { Mean } \\
\text { Squares }\end{array}$ & $\begin{array}{c}\mathbf{F} \\
\text { value }\end{array}$ & \multicolumn{2}{|c|}{$\mathbf{F}_{\text {table }}$} \\
\cline { 6 - 7 } & & & & & $\begin{array}{r}\alpha=05 \\
0,01\end{array}$ \\
\hline Total & 74 & 1713505 & & & & \\
\hline Reg (a) & 1 & 1673711 & 1673711 & & & \\
\hline $\begin{array}{r}\text { Reg } \\
\text { (b/a) }\end{array}$ & 1 & 2283,8 & 2283,8 & 4,3838 & 3,96 & 7,01 \\
\hline Residual & 72 & 37510 & 520,9692 & & & \\
\hline Tuna fit & 32 & -195317 & -6493 & $-1,396$ & 1,67 & 2,06 \\
\hline an error & 40 & 195317 & 4650,4 & & & \\
\hline
\end{tabular}


TABLE III. SIGNIFICANCE TESTS AND THE ANOVA FOR LINEARITY $\mathrm{X}_{2}=\mathrm{X}_{3}=92,902+0,0756 \mathrm{X}_{1}$

\begin{tabular}{|r|c|c|c|c|c|c|}
\hline Source & df & $\begin{array}{c}\text { Sum of } \\
\text { Squares }\end{array}$ & $\begin{array}{c}\text { Mean } \\
\text { Squares }\end{array}$ & $\begin{array}{c}\text { F } \\
\text { value }\end{array}$ & \multicolumn{2}{|c|}{$\mathbf{F}_{\text {table }}$} \\
& & & & & $\begin{array}{r}\alpha= \\
0,05\end{array}$ & 0,01 \\
\hline Total & 74 & 795620 & & & & \\
\hline Reg (a) & 1 & 787127 & 787127 & & & \\
\hline $\begin{array}{r}\text { Reg } \\
\text { (b/a) }\end{array}$ & 1 & 201,86 & 201,86 & 1,753 & 3,96 & 7,01 \\
\hline Residual & 72 & 8290,8 & 115,15 & & & \\
\hline Tuna fit & 48 & -8177 & $-170,4$ & $-0,248$ & 1,88 & 2,47 \\
\hline an error & 24 & --55800 & 686,16 & & & \\
\hline
\end{tabular}

\section{A. Testing of Hypotheses.}

First, Hypothesis testing to test that Behaviors Leadership $\left(\mathrm{X}_{1}\right)$ is a direct influence and positive toward performance (Y). Hypotheses were tested as follows:

$\mathrm{H}_{\mathrm{o}:} \beta_{\mathrm{y} 1} \leq 0 \quad ; \mathrm{H}_{1:} \beta_{\mathrm{y} 1}>0$

The path coefficients value $\left(\rho y_{1}\right)$ of 0.231 , with $\mathrm{t}=2.012$, at $\alpha=0.05$, obtained $\mathrm{t}_{\text {able }}=1.67$. Because $\mathrm{t}_{\text {value }}=2.012>\mathrm{t}_{\text {table, }}$, then $\mathrm{H}_{\mathrm{o}}$ is rejected and received $\mathrm{H}_{1}$, which means the path coefficients are significant. The findings can be interpreted that of Leadership Behaviors a positive direct impact on .performance. Second, Hypothesis testing to prove that SelfLearning $\left(\mathrm{X}_{2}\right)$ direct positive influence on performance $(\mathrm{Y})$. Hypotheses were tested as follows:

$\mathrm{H}_{\mathrm{o}}: \beta_{\mathrm{y} 2} \leq 0 \quad ; \mathrm{H}_{1:} \beta_{\mathrm{y} 2}>0$

The path coefficients value $\left(\rho y_{2}\right)$ of 0.253 , with $\mathrm{t}=2.217$, at $\alpha=0.05$, obtained $t_{\text {table }}=1.67$. Because $t_{\text {value }}=2.217>\mathrm{t}$ table, then $\mathrm{H}_{\mathrm{o}}$ is rejected and accepted. $\mathrm{H}_{1}$, which means the path coefficients is significant. The findings can be interpreted that of Self-Learning a positive direct impact on performance. Third, Hypothesis testing to prove that Behaviors of Leadership $\left(\mathrm{X}_{1}\right)$ a positive direct influence on Self Learning $\left(\mathrm{X}_{2}\right)$. Third, Hypothesis testing to prove that Behaviors Leadership $\left(\mathrm{X}_{1}\right)$ direct positive influence on Hypothesis testing to prove that Behaviors Leadership $\left(\mathrm{X}_{1}\right)$ direct positive influence on performance $\left(\mathrm{X}_{2}\right)$. From the calculation of, on show from table 4 is coefficient value $\left(\rho y_{1}\right)=0.062, t=0.569$, at $\alpha=0.05$, the obtained from table is $=1.67$, because the value of $0.569<1,671$, then $H_{0}$ is accepted, $H_{1}$ is rejected, which means that interpreted there are no positive direct influence of Leadership Behaviors on self-learning.

TABLE IV. COEFFICIENTS OF SUB-STRUCTURE

\begin{tabular}{|c|c|c|c|c|c|c|}
\hline \multicolumn{7}{|c|}{ Coefficients $^{\mathrm{a}}$} \\
\hline \multirow{2}{*}{\multicolumn{2}{|c|}{ Model }} & \multicolumn{2}{|c|}{$\begin{array}{c}\text { Unstandardized } \\
\text { Coefficients }\end{array}$} & \multirow{2}{*}{$\begin{array}{c}\begin{array}{c}\text { Standardized } \\
\text { Coefficients }\end{array} \\
\text { Beta }\end{array}$} & \multirow[b]{2}{*}{ t } & \multirow[b]{2}{*}{ Sig. } \\
\hline & & B & $\begin{array}{l}\text { Std. } \\
\text { Error }\end{array}$ & & & \\
\hline \multirow[t]{3}{*}{1} & $\begin{array}{c}\text { (Constan } \\
\text { t) }\end{array}$ & 61.882 & 9.025 & & 6.857 & .000 \\
\hline & $\mathrm{X} 1$ & .031 & .054 & .062 & .569 & .571 \\
\hline & $\mathrm{X} 2$ & .299 & .077 & .425 & 3.870 & .000 \\
\hline
\end{tabular}

\section{B. Discussion}

The goal of the present study was to see effect direct influence and positive between leadership behavior, selflearning, and performance of teachers. This is in line with the study from Barling [24] that the leadership behavior gives a positive or negative influence. But, from this research that leadership behavior is not affect direct influence and positive on teachers self-learning. The results of this research were relevant from research conducted Gilberg Austin about the school principal at the Maryland United States, which claimed that there are differences between high-performing schools and low that was the result of the influence of the school principal leadership [25]. It also showed that teacher as an important human resource in schools, in what is done with regard to the tasks and functions who important from principal as a leader. Leadership behavior is the core of the formation of the teacher's performance in school and played an important role in the effectiveness at school. For the Leadership behavior, either task-oriented or relationship its that were equally important for a leader in relation to the overall performance of a work unit [19]. The research hypothesis was proved that self-learning had direct influence and positive toward performance. It shows that the result of learning is an important thing in job's performance [2] [16].

Self-learning is an essentially the learning applies to adults who already have a concept of self or self-maturity who have understood the purpose of what it does. Learning aimed at adults who have had experiences that made one of the bases for developing his/her potential also experience acquired skills through self-learning conduct expected some changes towards more good. Therefore, however, a teacher must and don't stop learning. A teacher is a role model in class and what is teacher do will impact to the student. That is relevance in study C.Pianta [26] about Relationships between children and teachers: Associations with classroom and home behavior. Self-learning is self-consciousness of a man who can see who she was or in other words has a self-concept. we know that to the achievement we need learning and the learning must continue in life. everyone has learning styles because of everyone individual difference [27] and for that we need selflearning. The teacher that related to the duties and role to facing the challenges and global competition will force to the "competed" in the sense of positive competition. The teacher that related to the duties and role to facing the challenges and global competition will force to the "competed" in the sense of positive competition. The teacher that related to the duties and role to facing the challenges and global competition will force to the "competed" in the sense of positive competition. It is indispensable for the human resources that are reliable and qualified. If the establishment is charged to the education of human resources, the education must be able to form its quality and powerful force. The teacher as one of the academic staff responsible for the challenges and the global competition. How do teachers playing the challenges of the roles and duties as educators? For that teacher themselves are required and are responsible for his proposition through his roles with the establishment of a positive work culture in a sense reflects their professionalism as an educator with 4 (four) competencies with awareness to have a high of self-learning. 
The teacher must always be developed on Potential or capacity with no effort his or her learning. Learning self-has made teachers whose direction to increases the capacity or potential. To increase capacity, it makes the teacher as a creative individual. The creativity of the teacher will be able to form teachers to create a positive on work culture with the creation of a school environment that is conducive to learning. Besides, the independence of teachers in action learning also supports the establishment on work culture teacher, which will ultimately learn formed of culture learners. For a teacher that directly deal with students in the classroom.

The finding told that there is no direct influence of leadership behavior toward self-learning.by the unproven hypotheses of leadership behavior that had no direct positive influence toward self-learning showed that the teachers have had high self-learning which did not depend on leadership behavior. This fact will strengthen the theory as a base of selflearning concept. By this finding, could be said that there is no direct influence of leadership behavior toward self-learning. For the unproven hypotheses of leadership behavior that had no direct influence toward self-learning showed that the teachers had the high self-learning that did not depend on leadership behavior. This fact will strengthen the based theory of self-learning, which is self-concept theory, the theory of cognitivism, self-regulation, and the theory of intrinsic motivation. One's self-concept could be seen through his/her attitude as his/her real act (The Self-actualization). The Human as the organism which has the will to grow and at last caused the individual realizes his/her existence. The development that is happening will help the individual to form self-learning. Cognitivist as the theory of learning had stated that, in learning, first depend on the individual itself. As told in learning theory by [28], that learning is a process which ruled by the individual, actively. The ability of the individual which fully used for the development of the individual itself, start from the way of thinking, the hopes, that will influence the way of learning. The self-learning itself related to the concept of self-regulation, on how to manage you in learning. This also knows as self-regulated learning. Through this concept have stated that the one learns to have responsibility for his /her learning, but for the self-learning is how everyone to more make it learning for self and self to be learning and for that we need a learning. This refers to the flexibility. Means that learning which was not only done once but learning as many times through self (the contemplation) to have needed accomplishment.

\section{CONCLUSION}

Based on the findings, the performance of teachers directly and positively influenced by the behavior of the teacher leadership and self-learning. This shows that for the performance it's influence from outside and from self inside. One of the outsiders is leadership behavior.

The leadership behavior is not directly influenced on teacher self-learning. This is an indication that success of people was especially important and dependent upon itself because it relates to the competence and capability of the person. So, teachers must change their own mindset about learning to increase competence and capability to be a teacher who learns how to learn, it's not just as a teacher.

However, learning undertaken by teachers in the classroom to success was self-learning by the teachers on himself instead of depending on others, but it's to including the principal.

\section{REFERENCES}

[1] G. James, J. M. Ivancevich, and J. H. Donnelly, Organisasi Jilid 1, Perilaku, Struktur, Proses. Tangerang: Bina Rupa Aksara Publisher, 2002.

[2] Colquitt, Le Pine, and Wesson, Organizational Behavior Improving Performance and Commitment in the workplace. New York: McGrawHill, 2009.

[3] C. S. Velez, M. Lorenzo, and J. M, "Leadership: It's importance in the management of School Coexistence," Procedia-Soc. Behav. Sci., vol. 237, pp. 169-174, 2017.

[4] R. Stephen and T. A. Judge, Organizational Behavior, 13th Ed. America: Pearson Prentice Hall, 2009.

[5] R. M. Hodgetts and K. F. Donald, Management 2nd, 2nd Ed. New York: Prentice Hall. Inc, 1988.

[6] H. Usman, Manajemen, Teori, Praktek, dan Riset Pendidikan. Jakarta Timur: PT. Bumi Aksara, 2009.

[7] P. Winne, "A Perspective on State of the art-research on Self-Regulated Learning.," vol. Instr. Sci,33, pp. 559-565, 2005.

[8] "The role of goal orientation in self-regulated learning" in Handbook of Self-Regulated Learning, M. Boekaerts, P.R. Print rich and M. Zeidner. San Diego: CA: Academic Press, 2000.

[9] M. Pholboon, W. Pochanukul, J. Tammachart, and K. Na Badulung, "Development of Continuing Motivation Via Distance Learning Model in Unrest Southernmost Provinces, Thailand," Procedia-Soc. Behav. Sci., vol. 174, pp. 2616-2621, 2015.

[10] G. Consuelo, Project-Based Learning in virtual groups-Collaboration and Learning Outcomes a virtual training course for teachers. ProcediaSocial and Behavioral Science 228, 2015.

[11] R. Zonoubi, A. Eslami Rasekh, and M. Tavakoli, "EFL teacher selfefficacy development in professional learning communities," System, vol. 66, pp. 1-12, Jun. 2017.

[12] B. Zimmerman J., "Investigating Sel-Regulation and Motivation: Historical background, Methodological Development, and future prospects.," Educ Res J, vol. 45, pp. 166-183, 2008.

[13] J. Rio-Fernandes, J. A. Cecchini, A. M. Gimenez, D. M. Alonso, and J. A. Prieto, "Self-Regulation, Cooperative Learning, Academic SelfEfficacy: Interactions to Prevent School Failure," Front. Psychol., 2017.

[14] John A and H. John R, Management of Organizational Behavior. Englewood Cliffs, New Jersey: Prentice Hall. Inc, 1992.

[15] J. M. Ivancevich, R. Konopask, and M. T. Matteson, Organizational Behavior and Management, Ninth edition. New York: McGraw-Hill, 2011.

[16] F. W. Hill, Theories of Learning, Translation, 5th Ed. Bandung: Nusa Media, 2011.

[17] A. Li, K. D. McCauley, and J. A. Shaffer, "The influence of leadership behavior on employee work-family outcomes: A review and research agenda," Hum. Resource. Manag. Rev., vol. 27, no. 3, pp. 458-472, Sep. 2017.

[18] E. I. A. Lester, "Chapter 40 - Leadership," in Project Management, Planning and Control (Seventh Edition), Butterworth-Heinemann, 2017, pp. 379-386.

[19] Y. Garry, Leadership in Organizations. Englewood Cliffs, New Jersey: Prentice Hall. Inc, 1981.

[20] H. V. Rivai and S. Murni, Education Management AnalisisTeori dan Praktik, Cetakan ke 3. Jakarta: Rajawali Pers, 2009.

[21] E. Panadero, A. Jonsson, and J. Botella, "Effects of self-assessment on self-regulated learning and self-efficacy: Four meta-analyses," Educ. Res. Rev.

[22] "Competency oy Adult Learners in Learning: Application of the Iceberg Competency Model.," Procedia-Soc. Behav. Sci., vol. 204, pp. 326-334.

[23] Cohran W.G, Sampling Techniques. New York: John Wiley and Sons, 1977. 
[24] J. Barling, A. Akers, and D. Beiko, "The impact of positive and negative intraoperative surgeons' leadership behaviors on surgical team performance," Am. J. Surg., Jul. 2017.

[25] A. Asrori M, "Pengaruh Perilaku Kepemimpinan Terhadap Kinerja Guru," http://www.majalah pendidikan.com/2011/04/.

[26] R. C. Pianta and S. L. Nimetz, "Relationships between children and teachers: Associations with classroom and home behavior," J. Appl. Dev. Psychol., vol. 12, no. 3, pp. 379-393, Jul. 1991.
[27] D. An and M. Carr, "Learning styles theory fails to explain learning and achievement: Recommendations for alternative approaches," Personal. Individual. Differ., vol. 116, pp. 410-416, Oct. 2017

[28] M. Jamaris, Orientasi Baru Dalam Psikologi Pendidikan. Jakarta: Yayasan Penamas Murni 